\title{
What deters plant colonization in a tropical pine plantation?
}

\author{
Zdravko Baruch $^{1,2^{*}}$, Erica Johnson ${ }^{1} \&$ Edgard Yerena ${ }^{1}$ \\ 1. Dpto. Estudios Ambientales, Universidad Simón Bolívar. Aptdo. 89000. Caracas, Venezuela; \\ johnson.ojeda@gmail.com, eayerena@yahoo.com \\ 2. School of Biological Sciences, University of Adelaide, North Terrace 5000, South Australia, Australia; \\ zdravko.baruch@adelaide.edu.au \\ * Correspondence
}

Received 16-VI-2015. C Corrected 14-I-2016. $\quad$ Accepted 16-II-2016.

\begin{abstract}
Pine plantations in the tropics are often employed to recondition eroded slopes from mudslides, as the Pinus caribaea plantation that shields the Universidad Simón Bolívar campus in Caracas (Venezuela). However, mismanagement of this plantation has led to its rapid degradation. The best option to maintain the protective service is to restore the plantation and direct its successional trajectory towards the neighbouring montane forest. Through experimental manipulation, we aimed to determine which factors block secondary succession and to investigate their effects. Within the experimental constraints imposed by the plantation small area, we analysed the effects of light and fertility limitation, litter accumulation and access to seed on plantation restoration. Light availability was manipulated by clearing and thinning three $800 \mathrm{~m}^{2}$ main plots. Fertilization and litter removal was applied to sub-plots within the light plots. Soils were analysed, microclimate was monitored and, for four years, stem density, species richness and basal area were tallied. Our results showed that light accessibility was the main factor deterring the successional trajectory of the plots, with varying grades of interaction with the sub-treatments. By the end of the fourth year, the cleared plot showed the largest responses in all traits (triplicating stem density and basal area and $>20$ times higher species richness). The main colonizers were Croton megalodendron, Ocotea fendleri, and Clusia spp. all dominant trees in the nearby native forest. We concluded that the results of this pioneer study, showed that small clearings, repeated in 3-4 year cycles are appropriate for similar restoration schemes. This procedure would create a mosaic of vegetation patches at different successional stages while protecting the slopes from erosion and increasing local biodiversity. Rev. Biol. Trop. 64 (2): 461-471. Epub 2016 June 01.
\end{abstract}

Key words: light limitation, passive restoration, pine needle litter, Pinus caribaea, Venezuela.

Since colonial times, Neotropical montane forests have been severely degraded by deforestation for firewood, charcoal manufacture and cultivation. Afterwards, recurrent fires blocked secondary succession and the slopes became subjected to erosion and mudslides. In some instances, protective reforestation of these areas was attempted, mostly with Pinus species (FAO, 2010) as they establish rapidly, grow fast and propagate easily. However, tropical pine species are short-lived and their plantations are frequently mismanaged leading to degradation and fire hazards. Consequently, to continue providing the required protection services, they must be restored. This approach has been attempted in the tropics and its success in promoting secondary succession is highly site specific (Ashton et al., 2014). It is subjected to local climate and soils (Fimbel \& Fimbel, 1996), plantation age (Lugo, 1992), proximity to seed sources and their dispersers (Keenan, Woldring, Irvine, \& Jensen, 1997; Zanne \& Chapman, 2001) and management systems (Wadsworth, 2008). Furthermore, restoration in pine plantations is hindered by allelopathic metabolites from roots or litter that 
interfere with colonization and growth of successional species (Fernández et al., 2006; Nissanka, Mohotti, \& Wijetunga, 2005; Guerrero \& Bustamante, 2007).

The pine plantation of the Universidad Simón Bolívar (USB) Caracas (Venezuela) shields the campus from mudslides. Established $\sim 40$ years ago, the plantation also delivers recreational services, landscape amenity and educational and research opportunities. Since the plantation was providing excellent services it was never thinned as reforestation practice recommends. This management decision disregarded the limitations of tropical pines and that restoration was required to preserve their ecological value. The lack of clear ecological long-term goals has led to gradual plantation decline which offered us the opportunity to set a passive restoration research.

Our objective was to assess experimentally the effects of factors that prevent restoration and to discuss some management options which could accelerate and guide a desirable successional trajectory to resemble the adjacent montane forest. We evaluated the effects of pine clearing and thinning, combined with fertilization and litter removal, on the recruitment and growth of native species. To our knowledge, this is the first study of this type attempted in the Neotropical montane forest biome and its results may assist in the restoration of comparable pine plantations.

\section{MATERIALS AND METHODS}

Study site and experimental design: The plantation extends over 48 ha $\left(10^{\circ} 24^{\prime} \mathrm{N}-66^{\circ} 53^{\prime}\right.$ W; 1 100-1 450 masl; Fig. 1A.) on slopes previously covered with secondary scrub and savanna which had encroached after deforestation of the montane forest. Reforestation was done mostly with Caribbean pine (Pinus caribaea Mortelet) (AGROFORCA, 1990). The study site is on $15-30 \%$ slopes, over quarzitic schists, capped by shallow, acidic and unfertile soils. The climate is temperate with most rainfall from May to December. On its Southern edge, 20-30 m separate the plantation from a 103 ha fragment of montane forest (Baruch \& Nozawa, 2014; Fig. 1A.) which is a potential seed source for plantation recruitment. Currently, formal status of the whole area is catalogued as "a conserved or protected zone". Its use is restricted to a few sport activities along trails and its management includes relative safeguard from fire and human encroachment.

The small area and the protective role of the USB plantation constrained the experimental design which impeded replication. We selected one $2400 \mathrm{~m}^{2}(60 \times 40 \mathrm{~m})$ area and divided it into three $800 \mathrm{~m}^{2}(20 \times 40 \mathrm{~m})$ main plots. Light availability treatments were imposed by manipulating pine density and were randomly assigned to plots by: (1) clearing all pines (L100); (2) thinning approximately half of the pines (L50); and (3) leaving the control plot intact (L0) (Fig. 1B). Timber felling and log disposal might have damaged some undergrowth plants and pine regeneration was nil. Within each main plot, twelve $15 \mathrm{~m}^{2}(3 \mathrm{x}$ $5 \mathrm{~m}$ ) sub-plots were established and delimited. Four sub-treatments were randomly assigned to three replicated sub-plots: (1) untreated controls (sub-treatment C); (2) raking of the litter (sub-treatment A); (3) litter removal by fire (sub-treatment F); and (4) fertilizer application with granulated NPK (15-15-15) at $200 \mathrm{~kg} / \mathrm{ha}$ (sub-treatment N) (Fig. 1B). The remaining of each main plot area $\left(620 \mathrm{~m}^{2}\right)$ was divided into four quadrants of $155 \mathrm{~m}^{2}$ for additional vegetation sampling (Fig. 1B). Vegetation was left to regenerate either by recruitment or by continued growth (or death) of that already present (Fig. 1C).

Climate, microclimate and soils: A nearby climatological station provided long term (1972-1992) rainfall data. Throughout the study, air temperature, relative humidity and rainfall were recorded inside and outside the plantation with HoBo loggers (model H08-03208, ONSET, Bourne, MA, USA) and standard pluviometers. Canopy cover and leaf area index (LAI) were measured with hemispheric photography (Nikon, Cool-Pix 4500 and Fisheye Converter, FC-E8, 0.21x) taken from the centre 

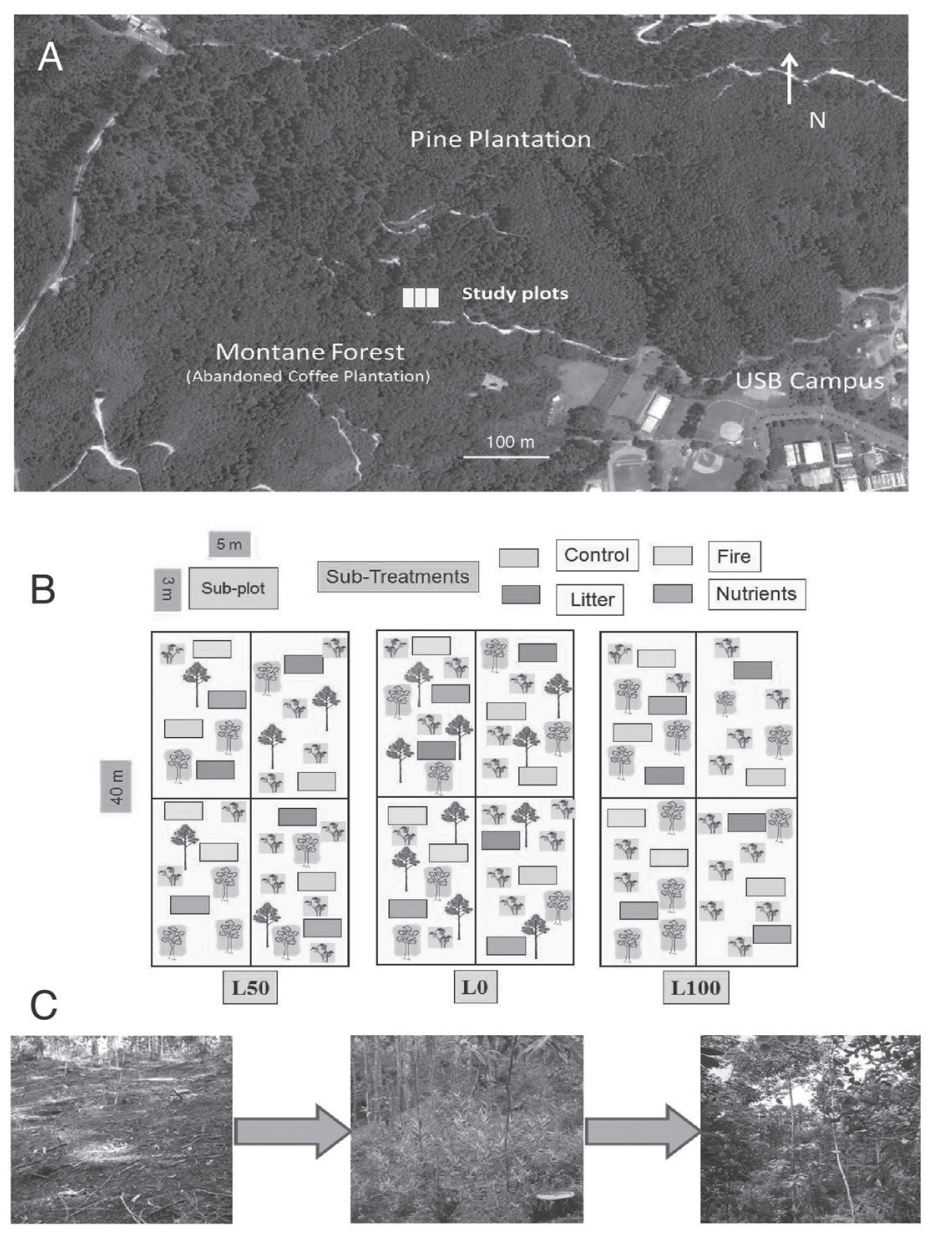

Fig. 1. (A) Pine plantation and adjacent montane forest showing site of experimental plots. Approximate scale 1:10.000. (B) Scheme of the experimental design of main plots, sub-treatment plots and quadrants. (C) Vistas of cleared plot (L100) from 2008 (left), 2009 (centre) and 2012 (right).

of four quadrants within intact plots. Images were analysed with HemiView software (DeltaT Devices Ltd., Houston, TX, USA).

Nine months after imposing the sub-treatments, one soil sample was collected from the centre of each of the 36 sub-plots. After airdrying, texture was obtained by the Bouyoucos technique, available phosphorus was analysed with the molybdic-blue method (Murphy \& Riley, 1963), whereas potassium and calcium were determined by flame spectrophotometry. Total nitrogen was analysed after Kjehdal digestion. Cation exchange capacity (CEC) and exchangeable aluminium content were analysed by extracting with $\mathrm{NH}_{4} \mathrm{Cl}$, followed by spectrophotometry (Sparks et al., 1996). Organic matter (Walkley \& Black's method; Jackson, 1982) and $\mathrm{pH}$ (1: 2.5 in water) were also measured. A synthetic integrated fertility index (FI) was calculated for each plot as the sum of the relative values (with respect to their maximum) of $\mathrm{N}, \mathrm{P}$ and $\mathrm{CEC}$ (maximum $\mathrm{FI}=$ 300). Soil apparent bulk density was tested on four samples per plot, and soil litter was collected with a circular sampler from 12 plot locations, oven-dried and weighed. Throughout 
the study, soil water content (SWC), at $5 \mathrm{~cm}$ $-10 \mathrm{~cm}$ depth, was analysed gravimetrically, on six samples per main plot.

Vegetation sampling and monitoring: In all sub-plots and quadrants, tree and shrub individuals with diameter at breast height $(\mathrm{DBH})$ $>1 \mathrm{~cm}$ were identified, tallied and labelled with metallic tags. DBH at $\sim 1.3 \mathrm{~m}$ above soil was obtained by averaging two perpendicular diameters and converted to basal area (BA). Stem diameter of shorter individuals was taken below the first branching. The presence and abundance of herbaceous vegetation and woody saplings $<1 \mathrm{~cm}$ DBH were visually estimated. Botanical samples were collected, photographed, processed and identified as in Hokche, Berry, \& Huber (2008). Vouchers are deposited in the USB herbarium. When identification was impossible, individuals were assigned to family or morphotype. Surveys were performed at the end of the rainy season (October-January) from 2008 to 2012. Due to logistical issues, the last census could not be completed.

Within the limitations of available experimental area stated above, we considered the three main light plots as blocks for treatment comparisons. Differences in soil properties among treatments were tested with a two-way ANOVA (SYSTAT, 2002). To avoid interference caused by remaining pre-treatment vegetation within plots, we analysed only yearly vegetation traits changes after the initial 2008 survey. To ease interpretation of differences between sub-treatments, only differences between initial and final results were analysed. Due to lack of multivariate normality in vegetation traits results, one and two-factor PerMANOVA tests were applied to differences between plots, treatments and years (PC-Ord; McCune \& Mefford, 2011). To better represent multivariate data, we drew polygons of ordered plots within the vegetation trait space obtained by principal component analysis (PCA) and indicated by successional vectors (PC-Ord; McCune \& Mefford, 2011).

\section{RESULTS}

Climate, microclimate and soils: Climate is relatively mild $\left(20.2{ }^{\circ} \mathrm{C}\right.$ mean temperature $)$ and long term mean rainfall is $1006.1 \mathrm{~mm}$ but with large inter-annual variation. Through the study, year 2009 was relatively dry (673.8 $\mathrm{mm}$ ), 2010 and 2011 were wet (1546.5 and $1607.8 \mathrm{~mm}$, respectively), whereas 2012 has close to average rainfall $(1113.9 \mathrm{~mm})$. Pine canopy retained $24.1 \pm 6.3 \%$ of rainfall. Before clearing and thinning, the plots did not differ in canopy cover or LAI (Table 1) which buffered the microclimate. In consequence, maximum mean and absolute temperatures as well as the temperature range were the highest in the cleared plot, whereas air relative humidity was always the lowest (Table 1).

Soils were unfertile and acidic sandy loams (Table 2). Needle litter accumulated up to $30 \mathrm{~cm}$ in depth and averaged $2.01 \pm 0.43$ $\mathrm{kg} / \mathrm{m}^{2}$, whereas soil bulk density was 1.10 $\pm 0.15 \mathrm{~g} / \mathrm{cm}^{3}$. Soils from the sub-treatments differed significantly in $\mathrm{N}, \mathrm{C}$, and $\mathrm{K}$ concentration, CEC and in FI (Table 3). Those from the burned needle sub-treatments (F) were expected to show the lowest nutrient content and FI, whereas fertilization sub-treatments (N) were expected to show the highest values. However, neither was supported by the results. SWC mirrored canopy interception, seasonality and yearly rainfall; it was always the highest in the cleared plot. During the dry season of the "dry" year (2009), the cleared plot averaged $35 \%$ more SWC than in the intact plot.

Vegetation traits: Vegetation changes were the fastest in the cleared plot where, after the first rainy season, tall and dense graminoids colonized and overtopped recruited seedlings. By the last survey, graminoids had almost disappeared and 47 woody species from 21 families were tallied (Fig 1C). Owing to their high stem density and BA, Croton megalodendron (Euphorbiaceae), Ocotea fendleri (Lauraceae), Clusia spp. (Clusiaceae), Roupala montana (Proteaceae) and Myrcia fallax (Myrtaceae) were the most important trees. 
TABLE 1

Microclimate in the experimental plots

\begin{tabular}{lccc} 
& PLOT L100 & PLOT L0 & PLOT L50 \\
a-Temperature $\left({ }^{\circ} \mathrm{C}\right)$ & & & $24.5(2.1)$ \\
Mean Maximum & $26.6(3.2)$ & $24.9(2.3)$ & $16.8(0.9)$ \\
Mean Minimum & $16.6(1.0)$ & $16.6(1.0)$ & 7.7 \\
Range (Max - Min) & 9.9 & 8.3 & 30.7 \\
Max absolute & 36.3 & 30.0 & 13.8 \\
Min absolute & 13.6 & 13.9 & $73.7(14.2)$ \\
Relative Humidity (\%) & & & 34.0 \\
Mean minimum & $69.6(15.1)$ & $36.0(13.6)$ & $77.1(1.9)^{\mathrm{a}}$ \\
Min absolute & 26.5 & $67.7(3.0)^{\mathrm{a}}$ & $2.6(0.7)^{\mathrm{a}}$ \\
b-Radiation environment & & $1.9(0.1)^{\mathrm{a}}$ & \\
Canopy Cover $(\%)$ & $74.0(2.4)^{\mathrm{a}}$ & & \\
LAI & $2.0(0.3)^{\mathrm{a}}$ & & \\
\hline
\end{tabular}

L100 (cleared); L50 (thinned); L0 (control) a- Mean, range and absolute air temperature and relative humidity as monitored during 160 weeks. b- Radiation environment: Canopy cover and leaf area index (LAI) before clearing and thinning.

Standard deviations in parentheses. Values followed by the same superscript letter were not statistically different at $p<0.05$.

TABLE 2

Mean and standard deviation of soil physicochemical parameters* of sub- treatments within main light plots

\begin{tabular}{|c|c|c|c|c|c|c|c|c|c|c|}
\hline PLOT & Sub-Treat & Sand & $\mathrm{pH}$ & $\mathrm{N}$ & CEC & $\mathrm{Ca}$ & K & $P$ & $\mathrm{OM}$ & FI \\
\hline \multirow[t]{2}{*}{ L100 } & Control & 47.88 & 4.50 & 0.11 & 8.31 & 0.40 & 0.03 & 4.33 & 4.57 & 151.18 \\
\hline & & 1.92 & 0.10 & 0.02 & 2.94 & 0.07 & 0.01 & 0.58 & 0.39 & 10.84 \\
\hline \multirow[t]{2}{*}{ L100 } & Fire & 49.30 & 4.63 & 0.15 & 7.90 & 0.40 & 0.04 & 5.67 & 4.34 & 184.38 \\
\hline & & 2.66 & 0.12 & 0.04 & 2.52 & 0.03 & 0.02 & 0.58 & 1.88 & 31.68 \\
\hline \multirow[t]{2}{*}{ L100 } & Raking & 48.13 & 4.53 & 0.10 & 10.27 & 0.39 & 0.05 & 4.00 & 3.63 & 149.54 \\
\hline & & 4.31 & 0.21 & 0.01 & 3.05 & 0.10 & 0.01 & 0.00 & 0.27 & 16.69 \\
\hline \multirow[t]{2}{*}{ L100 } & Fertilizer & 45.25 & 4.57 & 0.10 & 6.95 & 0.34 & 0.03 & 4.67 & 3.65 & 142.80 \\
\hline & & 0.76 & 0.25 & 0.01 & 1.80 & 0.02 & 0.01 & 0.58 & 0.67 & 6.28 \\
\hline \multirow[t]{2}{*}{ L50 } & Control & 44.05 & 4.37 & 0.15 & 15.91 & 0.44 & 0.07 & 4.33 & 4.95 & 206.36 \\
\hline & & 4.69 & 0.12 & 0.02 & 3.49 & 0.10 & 0.02 & 0.58 & 0.57 & 22.92 \\
\hline \multirow[t]{2}{*}{ L50 } & Fire & 47.75 & 4.70 & 0.12 & 11.04 & 0.54 & 0.04 & 4.33 & 3.85 & 169.93 \\
\hline & & 3.56 & 0.44 & 0.01 & 2.04 & 0.36 & 0.01 & 0.58 & 0.44 & 10.97 \\
\hline \multirow[t]{2}{*}{ L50 } & Raking & 44.54 & 4.57 & 0.12 & 11.32 & 0.44 & 0.06 & 4.33 & 3.73 & 169.43 \\
\hline & & 1.31 & 0.12 & 0.01 & 3.10 & 0.11 & 0.01 & 0.58 & 0.33 & 13.75 \\
\hline \multirow[t]{2}{*}{ L50 } & Fertilizer & 45.04 & 4.53 & 0.13 & 15.45 & 0.52 & 0.06 & 5.33 & 4.88 & 204.17 \\
\hline & & 3.12 & 0.12 & 0.01 & 5.52 & 0.12 & 0.03 & 1.53 & 0.89 & 15.72 \\
\hline \multirow[t]{2}{*}{ L0 } & Control & 49.26 & 4.60 & 0.16 & 14.83 & 0.58 & 0.08 & 6.33 & 5.48 & 230.79 \\
\hline & & 3.00 & 0.17 & 0.02 & 1.37 & 0.20 & 0.02 & 2.31 & 1.00 & 35.21 \\
\hline \multirow[t]{2}{*}{ L0 } & Fire & 44.32 & 4.63 & 0.14 & 7.56 & 0.39 & 0.04 & 4.00 & 4.39 & 156.82 \\
\hline & & 2.20 & 0.06 & 0.03 & 3.65 & 0.04 & 0.02 & 0.00 & 0.73 & 10.23 \\
\hline \multirow[t]{2}{*}{ L0 } & Raking & 47.25 & 4.67 & 0.13 & 5.78 & 0.37 & 0.04 & 6.67 & 4.00 & 172.34 \\
\hline & & 5.67 & 0.12 & 0.02 & 2.22 & 0.15 & 0.02 & 2.52 & 0.59 & 14.37 \\
\hline \multirow[t]{2}{*}{ L0 } & Fertilizer & 48.25 & 4.60 & 0.13 & 8.22 & 0.46 & 0.04 & 5.00 & 4.06 & 167.41 \\
\hline & & 4.36 & 0.17 & 0.03 & 5.28 & 0.12 & 0.03 & 1.73 & 0.81 & 28.47 \\
\hline
\end{tabular}

*Total N (\%), available P (ppm), Organic matter (OM, \%), Sand (\%). Fertility index (FI; max = 300). Cation Exchange Capacity (CEC), Ca, K (cmol/kg). 
TABLE 3

Two-way ANOVA of selected soil traits

\begin{tabular}{lllc}
\multicolumn{1}{c}{ Variable } & \multicolumn{1}{c}{ Source } & \multicolumn{1}{c}{$\mathrm{F}_{\text {-ratio }}$} & $\mathrm{P}$ \\
NITROGEN & PLOT & $\mathrm{F}_{(2,24)}=3.67$ & 0.040 \\
& TREATMENT & $\mathrm{F}_{(3,24)}=3.40$ & 0.340 \\
INTERACTION & $\mathrm{F}_{(6,24)}=1.77$ & 0.147 \\
CARBON & PLOT & $\mathrm{F}_{(2,24)}=0.87$ & 0.420 \\
& TREATMENT & $\mathrm{F}_{(3,24)}=3.43$ & 0.033 \\
CEC & INTERACTION & $\mathrm{F}_{(6,24)}=0.77$ & 0.594 \\
& PLOT & $\mathrm{F}_{(2,24)}=8.18$ & 0.002 \\
MAGNESIUM & TREATMENT & $\mathrm{F}_{(3,24)}=2.97$ & 0.050 \\
& INTERACTION & $\mathrm{F}_{(6,24)}=1.83$ & 0.134 \\
POTASSIUM & PLOT & $\mathrm{F}_{(2,24)}=4.84$ & 0.017 \\
& TREATMENT & $\mathrm{F}_{(3,24)}=2.11$ & 0.125 \\
& INTERACTION & $\mathrm{F}_{(6,24)}=1.79$ & 0.144 \\
FERTILITY INDEX & PLOT & $\mathrm{F}_{(2,24)}=3.30$ & 0.050 \\
& TREATMENT & $\mathrm{F}_{(3,24)}=2.66$ & 0.071 \\
& INTERACTION & $\mathrm{F}_{(6,24)}=2.15$ & 0.084 \\
& PLOT & $\mathrm{F}_{(2,24)}=7.76$ & 0.003 \\
& TREATMENT & $\mathrm{F}_{(3,24)}=4.45$ & 0.013 \\
& INTERACTION & $\mathrm{F}_{(6,24)}=4.68$ & 0.003 \\
\hline
\end{tabular}

Only variables with significant effects between main plots, sub-treatments and/or interactions are shown.

TABLE 4

Two-way PerMANOVA of differences between sub-treatments within the main plots

\begin{tabular}{cllc}
\multicolumn{1}{c}{ TRAIT } & \multicolumn{1}{c}{ Factor } & \multicolumn{1}{c}{$\mathrm{F}$} & $\mathrm{P}$ \\
Stem Density & Plot & $\mathrm{F}_{(2,35)}=19.02$ & 0.0002 \\
& Sub-treatment & $\mathrm{F}_{(2,35)}=2.31$ & 0.1180 \\
Species Richness & Interaction & $\mathrm{F}_{(4,35)}=2.13$ & 0.0092 \\
& Plot & $\mathrm{F}_{(2,35)}=10.57$ & 0.0002 \\
& Sub-treatment & $\mathrm{F}_{(2,35)}=1.05$ & 0.3660 \\
Basal Area & Interaction & $\mathrm{F}_{(4,35)}=1.03$ & 0.4280 \\
& Plot & $\mathrm{F}_{(2,35)}=0.93$ & 0.4000 \\
& Sub-treatment & $\mathrm{F}_{(2,35)}=0.27$ & 0.7580 \\
& Interaction & $\mathrm{F}_{(4,35)}=1.34$ & 0.2760 \\
\hline
\end{tabular}

Clearing increased stem density and species richness but BA was unaffected (Fig. 2 and Table 4$)$. The small area $\left(15 \mathrm{~m}^{2}\right)$ of the subtreatment plots was probably the main cause for the large differences among replicates (Fig. 2 ). The results from the much larger quadrants stress the positive effect of light availability on stem density and BA but not on species richness (Fig. 3 and Table 5). Also, year to year differences were significant in stem density and BA (Fig. 3 and Table 5). The large polygon area in the PCA ordination diagram, and the length of the successional vector (Fig. 4), confirms the pronounced multitrait changes promoted by increased light.

\section{DISCUSSION}

The initial densely sown pines, and subsequent absence of thinning, probably hindered understory recruitment by the combined effects of: (1) decreased light availability; 

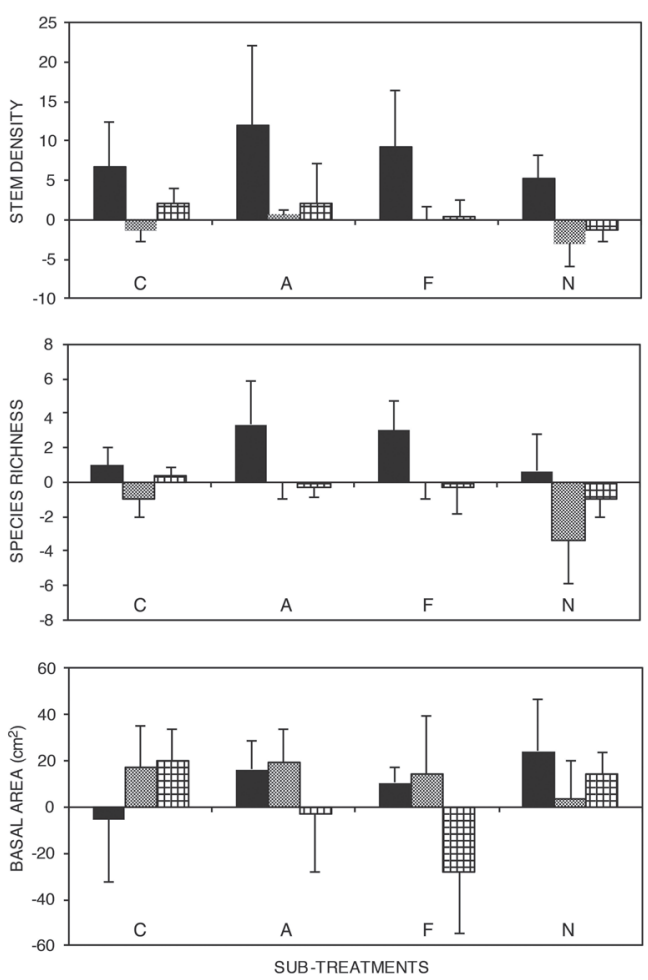

Fig. 2. Differences between the final (2011) and initial (2008) surveys values of stem density, species richness and basal area of the sub-plot treatments. Filled bar = cleared plot (L100); Grey bar = thinned plot (L50); Stripped bar = control plot (L0). Sub-treatments: $\mathrm{C}=$ Control; $\mathrm{A}=$ Litter removal by raking; $\mathrm{F}=$ Litter removal by fire; $\mathrm{N}=$ Nutrient addition.
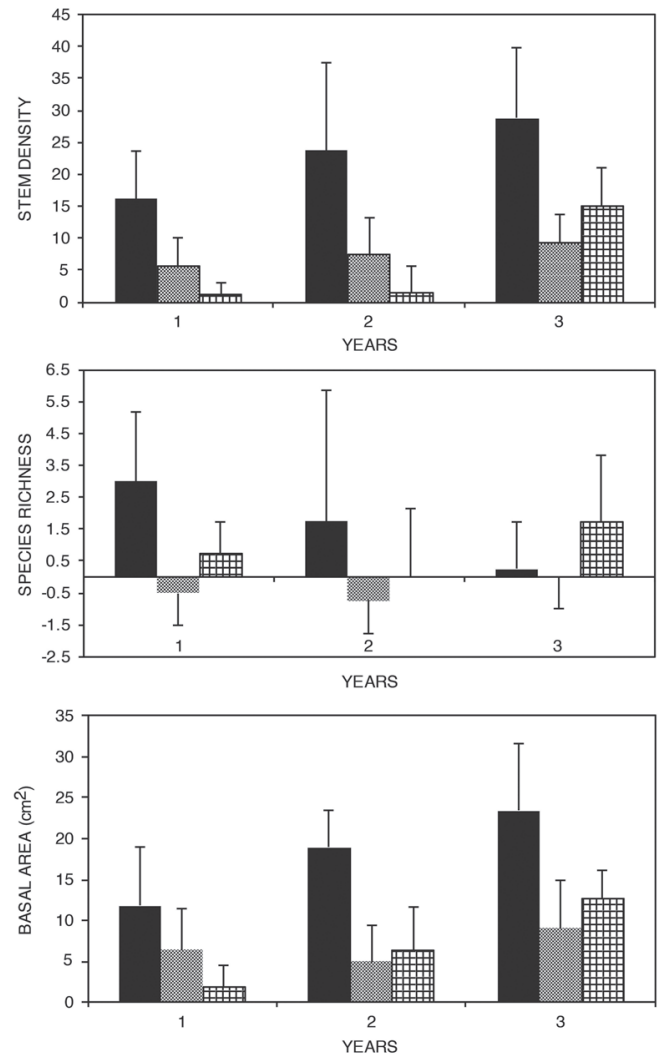

Fig. 3. Stem density, species richness and basal area of the quadrants from the main light plots through the study. (Filled bar $=$ cleared plot (L100); Grey bar $=$ thinned plot (L50); Stripped bar $=$ control plot (L0).

TABLE 5

Two-way PerMANOVA analysis of differences between main light plots, sampling years and their interaction

\begin{tabular}{cllc}
\multicolumn{1}{c}{ TRAIT } & \multicolumn{1}{c}{ Factor } & \multicolumn{1}{c}{$\mathrm{F}$} & $\mathrm{P}$ \\
Stem Density & Plot & $\mathrm{F}_{(2,35)}=12.31$ & $<0.0001$ \\
& Year & $\mathrm{F}_{(2,35)}=4.53$ & 0.0128 \\
\multirow{3}{*}{ Species Richness } & Interaction & $\mathrm{F}_{(4,35)}=0.67$ & 0.6290 \\
& Plot & $\mathrm{F}_{(2,35)}=3.15$ & 0.0570 \\
& Year & $\mathrm{F}_{(2,35)}=0.40$ & 0.6700 \\
Basal Area & Interaction & $\mathrm{F}_{(4,35)}=1.14$ & 0.0370 \\
& Plot & $\mathrm{F}_{(2,35)}=5.72$ & $<0.0001$ \\
& Year & $\mathrm{F}_{(2,35)}=3.15$ & 0.0140 \\
& Interaction & $\mathrm{F}_{(4,35)}=0.86$ & 0.5740 \\
\hline
\end{tabular}




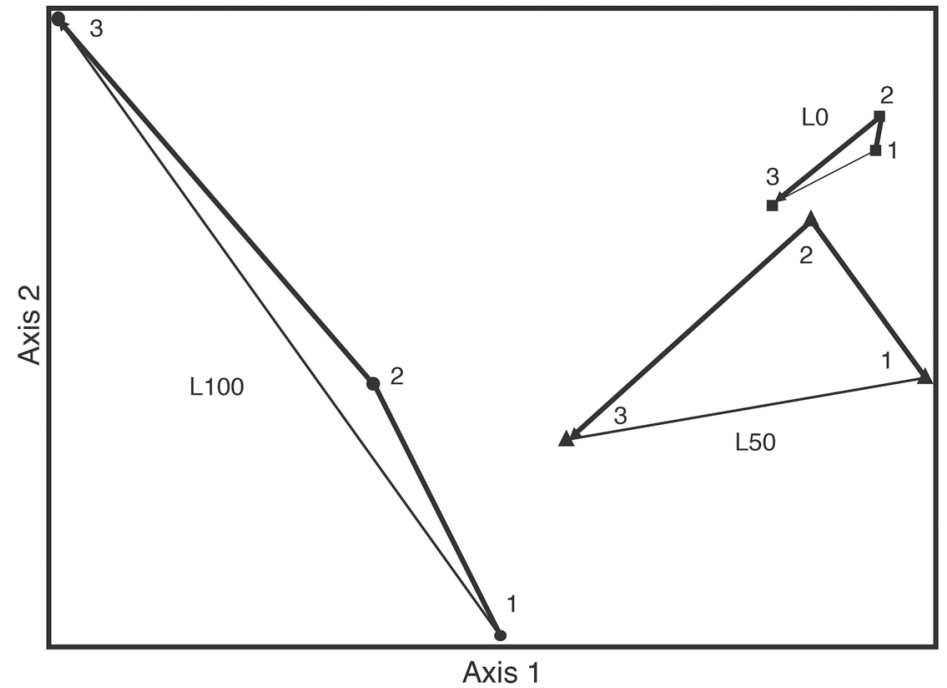

Fig. 4. First two axes of the PCA diagram of main plot vegetation traits. Arrows and bold lines show successional trajectories from 2008 to 2011 (numbers 1 to 3). Variance explained by the first PCA axis was $69.7 \%$.

(2) increased below-ground competition for soil nutrients and water; (3) huge cushions of recalcitrant litter and (4) restricted access to seed dispersers. The plantation canopy reduced incoming irradiance by $\approx 75 \%$, which repressed stem density and BA. Species richness was less affected by augmented irradiance, suggesting that species already present as seeds/seedlings, but suppressed by shade, were released after clearing, or that recruitment of a similar assemblage of species dispersed by animals or wind did take place. Although vegetation traits responded to plot thinning, it was considerably less effective in promoting colonization. Low light availability is recognized as the primary barrier for restoration in pine plantations (Ashton, Gamage, Gunatilleke, \& Gunatilleke, 1997; Gómez-Aparicio et al., 2009; De Abreu, de Assis, Aguirre, \& Durigan, 2011; Ashton et al., 2014), but canopy removal also has secondary deterring effects as a probable cause of water stress due to higher air temperature and lower humidity, which lead to higher evaporative demands. Another negative effect of canopy removal is the increased vulnerability to opportunistic species, such as the locally important alien tree Syzigium jambos (rose-apple) (Baruch \& Nozawa, 2014). However, by the end of this study, none had emerged in the experimental plots.

Plantation soils were unfertile, and when combined with low irradiance, restricted the performance of prospective colonizers. Experimental fertilization partially reversed this limitation increasing stem density and BA. Unimpeded rainfall impact in the cleared plot might have caused some nutrient leaching and reduced the effect of the fertilization treatment. Pine clearing and thinning possibly diminished competition for soil nutrients, but a longer study is required for confirmation. At our site, soil oligotrophy was caused by a combination of historical low soil fertility, immobilization of nutrients in the large and fast growing pine biomass (Berthrong, Jobbagy, \& Jackson, 2009), and by litter recalcitrance to decomposition delaying nutrient cycling, all common traits of pine plantations (Cavalier \& Tobler, 1998; Craine \& Orians, 2004; Gómez, Paolini, \& Hernández, 2008; León, González, \& Gallardo, 2011). Competition for soil water was probably another barrier to colonizers, considering that $\sim 25 \%$ of rainwater was retained and dissipated by the pine canopy, and that water shortage 
occurs periodically, such as during the 2009 dry season. Water shortage and elevated evaporative demand in the cleared plot might have desiccated seedlings, decreasing recruitment.

Dense pine canopies deposit thick cushions of leaf litter. The removal of this litter, either by fire or raking, significantly increased stem density but, unexpectedly, decreased BA. This pine needle layer reduces recruitment by hindering germination and/or seedling emergence physically as shown experimentally in the studied plantation (Bueno \& Baruch, 2011) and elsewhere (Izhaki, Henig-Sever, \& Neeman, 2000; Dodson, Peterson, \& Harrod, 2008; Fernández et al., 2006; Navarro-Cano, Barberá, \& Castillo, 2010) or through allelopathic effects (Nissanka et al., 2005; Guerrero \& Bustamante, 2007; Fernández et al., 2006). The desirable removal of the needle litter is challenging as fire could damage the seed bank and volatilize soil nutrients while raking is extremely arduous.

Proximity to seed source sped up colonization in the cleared plot. Twenty (42.5\%) of the 47 species recorded thrive in the neighbouring montane forest (Baruch \& Nozawa, 2014). Proximity to native vegetation is one of the major factors influencing restoration success (Zanne \& Chapman, 2001; Chazdon, 2003; Ashton et al., 2014) and it was a main factor considered in the selection of the study site. Although Caribbean pine crowns are unattractive to bird and bat dispersers (Keenan et al., 1997; Goodale et al., 2014), plot clearings appeal to those feeding on the fruits of the early colonizers (e.g. the shrub Clidemia hirta in the study site; Navas, 2010), which may disperse other tree seeds into these cleared plots. It is important to point out that despite the negative effects on succession discussed above; under certain circumstances a densely sown plantation might provide some benefits for restoration such as preventing understory pine recruitment and impeding invasive species encroachment.

We conclude that light availability was the main limitation to succession which overcame the effects of the other experimental factors of this study. By the end of the fourth year, the cleared plot showed the largest responses in all traits (three times higher stem density and BA and up to twenty times higher species richness) as compared to the thinned and control plots. The removal of this barrier to recruitment and growth resulted in a marked response of vegetation which appears to follow a successional trajectory towards the local montane forest. The assisted passive restoration applied here could be the strategy of choice to increase biodiversity while maintaining the protective services to the USB campus and to similar plantations. We recommend that pine clearing should start with small patches, close to the native seed source, followed by 3 to 4 years of stabilization for colonizer recruitment and establishment. Gradually, this clearingstabilization cycle would generate areas at different successional stages increasing local biodiversity and maintaining the protective role of the former plantation. This approach is low cost and can be conducted by unskilled workers or volunteers with few materials, but strict fire protection plus control of exotic invaders, must be effective.

\section{ACKNOWLEDGMENTS}

Decanatos de Investigaciones USB (Fondo de Trabajo), and Extensión USB, (Banco de Proyectos; BPDEx: 04-007) funded this work. We thank J. P. Lorenzo and J. P. Vivas and their warden team. We also thank the many volunteer students from the Communitary Work Group for field surveys, M. Loro for plant identification, D. Fernández for hemispheric images, and E. Zambrano for limited soil sampling and processing. M. Breed assisted with language editing and $\mathrm{E}$. Baruch with graphics.

\section{RESUMEN}

¿Cuáles son los factores que limitan la colonización vegetal en una plantación de pino tropical? En los trópicos, las plantaciones de pino se emplean comúnmente para proteger laderas erosionadas. Este es el caso de la plantación de Pinus caribaea que resguarda el campus de la Universidad Simón Bolívar en Caracas (Venezuela) de los deslaves de lodo. Sin embargo, el inadecuado manejo 
de la plantación está conduciendo a su rápido deterioro. La opción más adecuada para mantener el papel protector de la plantación es la restauración dirigida hacia una sucesión similar a la del bosque montano vecino. Mediante manipulaciones experimentales nos proponemos determinar cuáles son los factores que bloquean la sucesión secundaria e investigar sus efectos específicos. Dentro de las limitaciones impuestas por el reducido tamaño de la plantación y su rol protector, aquí analizamos los efectos de la reducida radiación solar y fertilidad del suelo, la acumulación de acículas de pino y el acceso a la fuente de semillas para la restauración. La disponibilidad de radiación solar se varió cortando y entresacando los pinos de parcelas de $800 \mathrm{~m}^{2}$. Los tratamientos de fertilidad y la remoción de acículas (por fuego y manualmente) se realizaron en subparcelas replicadas dentro de las parcelas principales. Los suelos se analizaron fisicoquímicamente, se monitoreo el microclima y, durante 4 años, se censó la densidad, el área basal y la riqueza de especies de los elementos leñosos en las parcelas. Los resultados muestran que el acceso a la radiación solar fue el factor principal que influyó sobre la colonización y crecimiento de nuevos individuos en las parcelas con diversos grados de interacción con los sub-tratamientos. Al finalizar el cuarto año, la parcela totalmente deforestada mostró las respuestas más elevadas (tres veces superior en cuanto a densidad y área basal y hasta veinte veces mayor en cuanto a riqueza de especies) comparada con las parcelas control y parcialmente deforestada. Las principales especies leñosas colonizadoras fueron: Croton megalodendron, Ocotea fendleri y Clusia spp., todas ellas dominantes en el bosque montano vecino. Concluimos que este estudio pionero muestra que el aclareo total de parcelas pequeñas, repetido en ciclos de 3-4 años es apropiado para proyectos de restauración similares. Así se obtendría un mosaico de vegetación en diferentes estadios sucesionales que mantienen el papel protector de la cubierta vegetal e incrementando la biodiversidad local.

Palabras clave: acículas, limitación lumínica, Pinus caribaea, restauración pasiva, Venezuela.

\section{REFERENCES}

AGROFORCA. (1990). Informe técnico forestal para realizar un aclareo en el bosque de pino de la Universidad Simón Bolivar. Caracas, Venezuela: Servicios Técnicos Agroforestales C.A.

Ashton, M. S., Gunatilleke, C. V. S., Gunatilleke, I. U. N., Singhakumara, B. M. P., Gamage, S., Shibayama, T., \& Tomimura, C. (2014). Restoration of rain forest beneath pine plantations: A relay floristic model with special application to tropical South Asia. Forest Ecology and Management, 329, 351-359.

Ashton, P. S., Gamage, S., Gunatilleke, I. U. N., \& Gunatilleke, C. V. S. (1997). Restoration of a Sri Lankan rainforest: Using Caribbean pine (Pinus caribaea) as a nurse for establishing late-successional tree species. Journal of Applied Ecology, 34, 915-925.

Baruch, Z. \& Nozawa, S. (2014). Abandoned coffee plantations: biodiversity conservation or path for non-native species? A case study from a Neotropical montane forest. Interciencia, 39, 554-561.

Berthrong, S. T., Jobbagy, E. B., \& Jackson, R. B. (2009). A global meta-analysis of soil exchangeable cations, $\mathrm{pH}$, carbon, and nitrogen with afforestation. Ecological Applications, 19, 2228-2241.

Bueno, A., \& Baruch, Z. (2011). Soil seed bank and the effect of the needle litter layer on seedling emergence in a tropical pine plantation. Revista de Biología Tropical, 59, 1071-1079.

Cavalier, J., \& Tobler, A. (1998). The effect of abandoned plantations of Pinus patula and Cupressus lusitanica on soils and regeneration of a tropical montane rain forest in Colombia. Biodiversity and Conservation, 7, 335-347.

Chazdon, R. L. (2003) Tropical forest recovery: legacies of human impact and natural disturbances. Perspectives in Plant Ecology, Evolution and Systematics, 6, 51-71.

Craine, S. I. \& Orians, C. M. (2004). Pitch pine (Pinus rigida Mill.) invasion of Cape Cod pond shores alters abiotic environment and inhibits indigenous herbaceous species. Biological Conservation, 116, 181-189.

De Abreu, R. C. R., de Assis, G. B., Aguirre, A., \& Durigan, G. (2011). Can native vegetation recover after slash pine cultivation in the Brazilian Savanna? Forest Ecology and Management, 262, 1452-1459.

Dodson, E. K., Peterson, D. W., \& Harrod, R. H. (2008). Understory vegetation response to thinning and burning restoration treatments in dry conifer forests of the eastern Cascades, USA. Forest Ecology and Management, 255, 3130-3140.

FAO (Food and Agriculture Organization of the United Nations) (2010). Global Forest Resources Assessment. Rome, Italy: FAO Forestry Paper 163.

Fernández, C., Lelong, B., Vila, B., Mévy, J-P., Robles, C., \& Greff, S. (2006). Potential allelopathic effect of Pinus halepensis in the secondary succession: an experimental approach. Chemoecology, 16, 97-105.

Fimbel, R. A., \& Fimbel, C. C. (1996). The role of exotic conifer plantations in rehabilitating degraded tropical forest lands: A case study from the Kibale Forest in Uganda. Forest Ecology and Management, 8, 215-226.

Gómez-Aparicio, L., Zavala, M. A., Bonet, F. J., \& Zamora, R. (2009). Are pine plantations valid tools for restoring Mediterranean forests? An assessment along 
abiotic and biotic gradients. Ecological Applications, 19, 2124-2141.

Gómez, Y., Paolini, J., \& Hernández, R. M. (2008). Sustitución de la sabana nativa con plantaciones de Pinus caribaea (Pinaceae) en Venezuela: efecto sobre parámetros indicadores de cambios en el carbono del suelo. Revista de Biología Tropical, 56, 2041-2053.

Goodale, E., Kottagama, S. W., Shankar Raman, T. R., Shidu, S., Goodale, U. M., Parker, S., \& Chen, J. (2014). The response of birds and mixed-species bird flocks to human modified landscapes in Sri Lanka and southern India. Forestry Ecology and Management, 329, 384-392.

Guerrero, P. C., \& Bustamante, R. O. (2007). Can native tree species regenerate in Pinus radiata plantations in Chile? Forest Ecology and Management, 253, 97-102.

Hokche, O., Berry, P. E., \& Huber, O. (Eds.) (2008). Nuevo Catálogo de la Flora Vascular de Venezuela. Caracas,Venezuela: Fundación Instituto Botánico de Venezuela "Dr. Tobías Lasser".

Izhaki, I., Henig-Sever, N., \& Neeman, G. (2000). Soil seed banks in Mediterranean Aleppo pine forests: the effect of heat, cover and ash on seedling emergence. Journal of Ecology, 88, 667-675.

Jackson, M. L. (1982). Análisis Químico de Suelos. Barcelona, España: Omega.

Keenan, R. D. L., Woldring, O., Irvine, T., \& Jensen, R. (1997). Restoration of plant biodiversity beneath tropical tree plantations in Northern Australia. Forestry Ecology and Management, 99, 17-131.

León, J. D., González, M. I., \& Gallardo, J. F. (2011). Biogeochemical cycles in natural forest and conifer plantations in the high mountains of Colombia. Revista de Biología Tropical, 59, 1883-1894.
Lugo, A. E. (1992). Comparison of tropical tree plantations with secondary forests of similar age. Ecological Monographs, 62, 1-41.

McCune, B., \& Mefford, M. J. (2011). PC-ORD Multivariate Analysis of Ecological Data. Ver. 6. MjM Software. Gleneden Beach, OR, USA.

Murphy, J., \& Riley, J. P. (1963). A modified single method for the determination of phosphate in natural waters. Analytical Chemical Acta, 27, 31-35.

Navarro-Cano, J. A., Barberá, G. G., \& Castillo, V. M. (2010). Pine litter from afforestation hinders the establishment of endemic plants in semiarid scrubby habitats of Natura 2000 Network. Restoration Ecology, 18, 165-169.

Navas, A. (2010). Dispersión de Semillas por Aves desde el Bosque Nativo hasta la Plantación de Pinos de la USB (Tesis de Licenciatura). Universidad Simón Bolívar. Caracas, Venezuela.

Nissanka, S. P., Mohotti, K. M., \& Wijetunga, A. S. T. B. (2005). Alleopathic influences of Pinus caribaea on vegetation regeneration and soil biodiversity. Fourth World Congress in Allelopathy. NSW, Australia: Charles Sturt University, Wagga Wagga.

Sparks, D. L., Page, A. L., Helmke, P. A., \& Loeppert, R. H. (Eds.) (1996). Methods of Soil Analysis. Part 3. Chemical Methods. Madison, WI, USA: SSSA book series 5.3.

SYSTAT (2002). SYSTAT for Windows v.10.0. Chicago, IL, USA: IBM SPSS Software.

Wadsworth, F. H. (2008). Growth of Pinus caribaea hondurensis relative to spacing and trunk diameter on two soils in Puerto Rico. Caribbean Journal of Science, 44, 236-241.

Zanne, A. E. \& Chapman, C. A. (2001). Expediting reforestation in tropical grasslands: Distance and isolation from seed sources in plantations. Ecological Applications, 11, 1610-1621. 
